\title{
ELLJ
}

\section{Platform work in Europe: The need for a multilevel solution to protect the so-called self-employed}

European Labour Law Journal 2022, Vol. I3(I) 8I-85 (C) The Author(s) 2021 Article reuse guidelines: sagepub.com/journals-permissions DOI: $10.1177 / 20319525211063113$ journals.sagepub.com/home/ell

@SAGE

\section{Gerrard Boot}

Professor, Department of Labour Law, Leiden University

\begin{abstract}
To protect the so-called self-employed, a multilevel solution is needed. Requalification is a first step and to do this, a broad definition of the employment agreement and the presumption of an employment agreement in some situations, is useful. But even then, a clear distinction between bogus self-employed and real entrepreneurs is sometimes difficult to make and requalification for the self-employed who work for individuals is problematic. Working on the base of a service contract gives some protection and besides that, protection for all working people is needed, such as, for example, a financial contribution in case of disability.
\end{abstract}

\section{Keywords}

presumption of employment, self-employment, protection for self-employed, multilevel solution

\section{Self-employed, changing minds}

On 13 March 2020 the social partners in the Netherlands (trade unions and employers'organisations) agreed on a disability insurance scheme for the self-employed. This insurance would be mandatory for the self-employed without personnel. Within one day different organisations representing the self-employed criticised the idea. They argued that the self-employed had no need for a forced insurance and they 'could help themselves'. ${ }^{\text {I }}$ One week later the first measures in response to the

1. Akkoord over verplichte aov voor zzp'ers: 'Toegankelijke en betaalbare regeling met keuzevrijheid'. Zzp-organisaties reageren verdeeld. - ZiPconomy; Schijnkeuzes en schijnzekerheid: STAR presenteert dubbelzinnig AOV plan - ZZP Servicedesk

\section{Corresponding author:}

Professor, Department of Labour Law, Leiden University.

E-mail: g.boot@rechtspraak.nl 
Coronavirus pandemic were taken: schools and restaurants were closed and public life almost came to a standstill. That same evening a self-employed worker who chaired professional meetings declared, on national television, that if this Coronavirus crisis lasted longer than two weeks, she would suffer financial problems; her business model was not prepared for it. The following day, the Dutch Minister of Economic Affairs announced financial support for the self-employed, but he added: 'we must not forget that they choose their position instead of an employment agreement.' ${ }^{, 2}$ This remark was heavily criticised: many self-employed workers were more or less forced to become self-employed, so it was argued. ${ }^{3}$

At the end of 2020 it was estimated that 7.9 million employees were supported with financial aid of EUR13.5 billion, while 1.6 million independent workers were supported with aid of EUR3.3 billion. While these figures are estimations, it seems that the financial support that independents got, as an average per person support, was a bit higher than employees. ${ }^{4}$

So, we see a lot of occasional arguments: as long as everything is going well, the better situated self-employed do not want their liberty restricted or financial obligations imposed on them. The less well situated or dependent self-employed workers are less vocal, but even they take an ambiguous position: if they are offered the opportunity to become an employee, they do not always accept the offer immediately. As to the legal position of platform workers, who according to their contract, are mostly not employees, there is not an one-size-fits-all easy solution. The solution should be tailormade.

\section{Requalification in some Member States}

Aloisi points out that rulings in disputes brought before higher courts favour the recognition of an employment relationship. ${ }^{5}$ He mentions the decision of the Spanish Supreme Court in September 2020 in the case involving Glovo food delivery riders ${ }^{6}$ and that of the French Cour de Cassation in March 2020 regarding Uber drivers. ${ }^{7}$ In January 2020 the Italian Supreme Court applied employment protection en bloc to a group of Foodora riders. ${ }^{8}$ In December 2020 the German Federal Labour Court stated that microtasks completed by crowdworkers can be classified as constituting an employment relationship. ${ }^{9}$ However, this jurisprudence does not exist in all Member States, and the CJEU took a somewhat reserved position in its ruling in the Yodel Case on April 22 $2020 .^{10}$ The same can be said of the decision of the London Court of Appeal on 24 June 2021 in the Deliveroo case, ${ }^{11}$ while the UK Supreme Court requalified the contract of Uber

2. Letterlijke tekst persconferentie ministers Wiebes, Hoekstra en Koolmees over economische maatregelen coronavirus | Mediatekst | Rijksoverheid.nl

3. FNV-voorzitter Han Busker: 'Opmerkingen minister Wiebes over zzp'ers en corona stuitend' - FNV Zelfstandigen - de vakbond voor zzp'ers (fnvzzp.nl)

4. The Netherlands Court of Audit; https://www.rekenkamer.nl/onderwerpen/corona/coronarekening; https://opendata.cbs. $\mathrm{nl} /$ statline/\#/CBS/nl/dataset/84166NED/table?ts=1609925821532;)

5. See an extensive overview in: C. Hiessl, The classification of platform workers in case law: A cross-European comparative analysis, ICF 2021.

6. Tribunal Supremo [Supreme Court] of 23 September 2020, 4746/2019 (Glovo).

7. Cour de Cassation (Supreme Court) of 4 March 2020, Arret n. 374 (19-13.316) (Uber).

8. Corte di Cassazione [Supreme Court] of 24 January 2020, RG n.11629/2019 (Foodora).

9. Bundesarbeidsgericht [Federal Labour Court] of 1 December 2020, 9 AZR 102/20 (Roamler).

10. CJEU, 22 April 2020, ECLI:EU:C:2020:288.

11. Court of Appeal, Deliveroo, 24 June 2021. 
workers. ${ }^{12}$ More than that, it is important to realise that the level of influence the platform has on the worker differs from platform to platform. The Dutch Supreme Court ruled on the Booking.com case in April 2021. ${ }^{13}$ The main question was whether Booking.com is an IT-company (with no collective labour agreement applicable) or part of the catering industry (with a collective labor agreement). The Advocate General at the Supreme Court ${ }^{14}$ considered it decisive whether the intention is to establish a contractual relationship between customer and, for example, the hotel, or between the customer and Booking.com. As Booking.com offers all kind of other products (rental cars, etc.) her conclusion was that the customer contracts with Booking.com. The Supreme Court followed this conclusion. The criterium suggested by the Advocate General is also useful for the qualification of other platform workers. A customer contacts the restaurant, or Foodora, and not the driver. Uber has an app through which the customer pays Uber, and the customer counts on a certain quality guaranteed by Uber, which in turn means that Uber has control over the drivers in a certain way. As a result, it is not so difficult to qualify the contract between Uber and the driver as an employment agreement. But other platforms are more open and they control their workers in a less clear way. This is one problem. The second is that to qualify a contract as an employment agreement, according to actual legislation, all facts must be taken into account. That causes a lot of uncertainty. Therefore, requalification en bloc could be useful. A third problem concerns the definition of the employment agreement, and the demarcation with entrepreneurship.

\section{Multilevel solution - defining the employment agreement}

I think a multilevel solution is needed. First of all, a broad definition of the employment agreement helps, and preferably, a definition that is as similar as possible for all EU-countries. In my opinion EU Directive 2019/1152 could play an important role in this because of the presumption of the employment agreement (Art. 15) and because the Directive contains a description (roughly a definition) of an employment agreement, where it refers (cons. 8) to certain jurisprudence of the CJEU. Of this jurisprudence, the well-known decisions in Isère, FNV KIEM and Rurhland provide useful connecting points. It is therefore important to develop these criteria more precisely. My attempt is as follows: (i) the word 'subordination' does not help, or at least will not be decisive. The difference between the (material) subordination in an employment agreement and the possibility of giving instructions in a service agreement is too unclear, because of the increasing level of education of many workers. The boss of these workers does not need to tell them what to do, or it may even be the case that the boss is not able to tell them what to do, because the employees are highly qualified. The idea of a 'formal subordination' (instead of the 'material subordination' I just described), however, could help. This means that the question of whether the worker is considered to be part of the organisation of the platform and whether he fulfills 'Betriebseigen' work for that organisation is important. ${ }^{15}$ (ii) In FNV KIEM, it was pointed out that an independent market position and a high level of freedom (in working time and place) are contra-indications of an employment agreement. I think that is right: if you are very good in a certain task, and you 'sell' yourself at a high rate to complete these tasks on behalf of a number of organisations, you should be allowed to do that. That

12. Supreme Court 19 February 2021, [2021] UKSC 5 (Uber).

13. Hoge Raad [Supreme Court], 9 April 2021, ECLI:NL:HR:2021:527 (Booking.com).

14. Advocate general (Ruth de Bock), 2 October 2020, ECLI:NL:PHR:2020:890.

15. 'Betriebseigen' means 'in-house'; work a company normally does itself. 
is a fundamental right, and there is no use in forbidding this practice. These people can help themselves; they do not need to be forced employees. Whether this is the case in reality should not be dependent on the presence of a written contract but must be considered looking at the facts. So, if a domestic cleaner earns so little that in reality there is no freedom to refuse work, then the worker does not occupy an independent market position and can easily be considered to be an employee.

\section{Presumption of employment}

In November 20202, the Dutch Government announced plans to develop the presumption of an employment agreement for platform workers, in the way Aloisi describes in paragraph 5 as 'a mix of the radical and the moderate option'. As certain criteria are met, the contract is presumed to be an employment agreement, with the possibility for the platform to prove the opposite. One problem with this presumption of employment in a certain jurisdiction is the question of whether this jurisdiction is applicable. We do not know where the server which distributes the tasks is based. Some tasks can be done from anywhere. I think this presumption can only work if the material work (like domestic cleaning or delivering food) is done in a certain country. That is contrary to the situation in respect of digital work, which can be done from anywhere.

\section{Duration of the contract}

Another problem is the duration of the contract. If the contract is for a very short duration, it is not practical (and in nobody's interest) to consider it to be an employment agreement. I would suggest that a limited period of work is a strong contra-indication of an employment agreement. Another possibility is to give the parties complete freedom to decide whether the contract is an employment agreement or not, if the work does not exceed a certain number of hours. Directive 2019/1152 gives as lower limit three hours per week, within a period of four weeks (so, 12 hours within four weeks, according to Article 1-3). That limit seems reasonable to me.

\section{Self-employed working for individuals}

However, even with an extended definition of the employment agreement, the problems are far from solved. Research in the Netherlands ${ }^{16}$ pointed out that almost $40 \%$ of the work fulfilled by self-employed, was done on behalf of individuals, rather than companies. Individuals (whether they are providing gardening, hair-cutting or cleaning services, or are taking care of children) are often not in the position to take on the proper role as employer. In certain areas - like caring or cleaning - it can be arranged for the work to be done through an agency, with the agency acting as employer, but that is not always possible. Therefore, for these self-employed workers, it does not really help to requalify their contract to an employment agreement. That brings me on my second point, which concerns the provision of social protection through other means than the employment agreement.

16. SEO November 2016, Characteristics and tariffs of self-employed 


\section{Social protection - an overview}

Social protection could be provided through means other than an employment agreement. This protection could be provided in different ways, individually organised or collectively. Let us start with individual social protection.

(i) Even in a service contract, certain rules apply, for example, in respect of the terms of notice and acting fairly vis-à-vis the other party. This could help higher-qualified self-employed workers, but I do not think it would work for platform workers, as most of the time they are doing small jobs.

(ii) Some type of protection could legally be proscribed for all workers. For example, in the Netherlands, non-employees are protected against the damages caused by work accidents, if the worker is dependent on the working conditions offered by the contractor (Art. 7:658-4 DCC). So, if an architect is on the construction site and falls into a concealed hole, he could sue the owner of the site for unsafe working conditions.

In respect of collective social protection, it is much easier to develop a certain level of protection for everybody, apart from having one contract or another. I previously referred to the disability insurance for the self-employed, agreed upon by Dutch social partners. It is also possible to have a national insurance, for example, for disability. This worked quite well in the Netherlands between 1976 and $1998 .{ }^{17}$ In France this development can be seen through the El Khomri laws. However, most of the time, this kind of protection only be provided at a minimum level.

\section{General conclusion}

The above discussion leads me to the conclusion that a multilevel solution is needed. We must broaden the scope of the employment agreement, and increase the level of protection for independent workers, both individually and collectively.

17. In 1998 the General Disability Law (AAW) was replaced by the Premiumdifferentation and Market Competion in Disability Insurance Law (PEMBA), in an attempt to introduce effective market competition. 